\title{
Effects of Nighttime Heating on Cell Size, Acid Invertase Activity, Sucrose Phosphate Synthase Activity, and Sugar Content of Melon Fruit
}

\author{
Jun Matsumoto, Hideyuki Goto, and Yasutaka Kano ${ }^{1}$ \\ Graduate School of Sciences for Bioproduction and Environment, Ishikawa Prefectural University, \\ Nonoichi, Ishikawa 921-8836, Japan

\begin{abstract}
Akira Kikuchi, Hideaki Ueda, and Yuta Nakatsubo
Department of Bioproduction Science, Ishikawa Prefectural University, Nonoichi, Ishikawa 921-8836, Japan
\end{abstract}

\begin{abstract}
AdDitional Index words. Cucumis melo, early cell enlargement, sucrose accumulation, enzyme, fruit heating
AbSTRaCt. To determine the relationship among cell size, acid invertase (AI) activity, sucrose phosphate synthase (SPS) activity, and sucrose accumulation in melon (Cucumis melo L.) during early development [from 6 to 16 days after anthesis (DAA)], fruit were heated at night to a minimum of $20^{\circ} \mathrm{C}$. Cells of heated fruit were larger than those of control fruit at 16 DAA but smaller at 50 DAA. AI activity was lower and SPS activity was higher in heated than in control fruit up to 26 DAA. Sucrose, glucose, and fructose contents at 26 and 50 DAA were higher in heated than in control fruit. Heating caused cells to reach mature size earlier than those of control fruit, and maturity was accompanied by earlier decline in AI activity and an earlier increase in SPS activity that promoted soluble sugar accumulation.
\end{abstract}

In Japan, melons grown in plastic film greenhouses during spring and shipped in early summer have low sucrose content. In this cultivation method, nighttime temperatures decrease to nearly $10{ }^{\circ} \mathrm{C}$ during early fruit development, and this likely accounts for the low sucrose content.

Nighttime heating of melon (Kano, 2006) or watermelon (Citrullus lanatus Matsum. et Nakai) during the early stages of fruit development (from 6 to 16 DAA) accelerated cell enlargement; consequently, there is high sucrose content in the fruit (Kano et al., 2008). Formation of increased numbers of larger cells in plants grown at warmer minimum temperatures during early fruit development (from anthesis to 32 DAA) was found to promote active sucrose accumulation in melon fruit (Kano and Fukuoka, 2006), and increased numbers of larger cells in japanese pear (Pyrus serotina Rehd.) treated with gibberellic acid also showed increased sucrose accumulation (Kano, 2003). In contrast, restricting fruit size by treatment with succinamic acid 2,2-dimethylhydrazide (Kano, 2004) or by mechanical means (Kano, 2009) reduced the number of large cells and suppressed sucrose accumulation in melon fruit. These results suggest that when sucrose is not needed for cell growth, it is stored in larger, mature cells.

Elevated sucrose level in melon fruit is associated with a decline in acid invertase activity (Chrost and Schmitz, 1997) and an increase in SPS activity (Gao et al., 1999; Hubbard et al., 1989; Hubbard and Pharr, 1990; Lingle and Dunlap, 1987). These results suggest that declining AI activity and increasing SPS activity are criteria for mature cells. We surmise that sucrose actively accumulates in large cells, and for the purpose of this study, we consider that larger cells are mature cells. Here, we test the hypothesis that nighttime heating of melon fruit causes

Received for publication 23 Apr. 2010. Accepted for publication 30 Sept. 2010 ${ }^{1}$ Corresponding author. E-mail: gansho@ishikawa-pu.ac.jp. early cell maturity, which, in turn, stimulates soluble sugar accumulation.

\section{Materials and Methods}

Plant materials and sampling. 'Earl's Knight Soshunbanshu' melon seeds were planted in a seed bed on 2 Mar. 2009, and nursery plants were spaced at $40-\mathrm{cm}$ intervals in a plastic film greenhouse on 5 Apr. Flowers $(n=30)$ that opened on 10 May were divided into two groups (heated and control) and used in this experiment. Fruit were held attached and fruit in the heated group were enclosed in polyvinylchloride boxes (Fig. 1) from 6 to 16 DAA (16 to 26 May) with a minimum nighttime temperature of $20^{\circ} \mathrm{C}$. Air temperature inside and outside the fruit heating boxes was measured hourly using a thermo recorder equipped with thermistors (TR-71S; T and D, Matsumoto, Japan). Control group fruit were grown in the same plastic film greenhouse without heating boxes. Fruit $(n=5)$ were harvested at the end of the heat treatment, 26 and 50 DAA, and the maximum longitudinal and latitudinal lengths of each fruit (designated as fruit length and diameter, respectively) and fresh weights were measured.

Fruit were cut in half latitudinally and two 20-mm-thick cross-sections were collected for analysis: the cross-section from the maximum transverse diameter toward the peduncle end was analyzed for biochemical analyses and one from the maximum transverse diameter toward the calyx end was analyzed for cell morphology (Fig. 2). A 40-mm-wide section was collected from both cross-sections and cut into $20 \times 10-\mathrm{mm}$ segments (L1-L5 and R5-R1) as shown in Figure 2.

Cell morphology. Segments L3 and R3 from the calyxside cross-section were analyzed for cell size and dehydrated in an ethanol series $[70 \%, 80 \%, 90 \%$, and $100 \%(\mathrm{v} / \mathrm{v})]$ before being embedded in paraffin. Seven $10-\mu$ m-thick sections were prepared from each paraffin block, and the clearest section from 


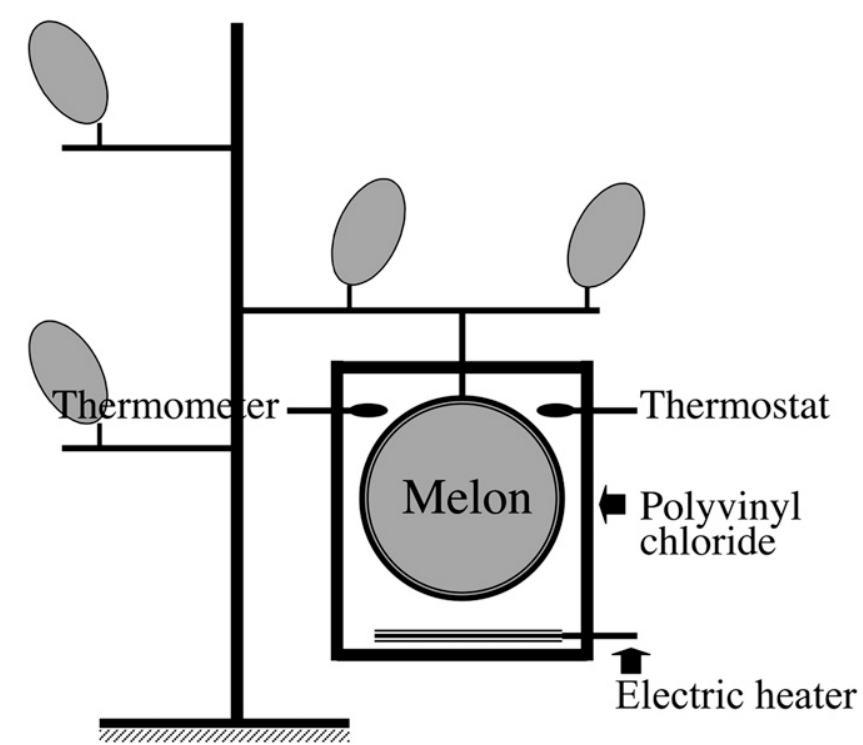

Fig. 1. A schematic of using of heating apparatus to warm melon fruit. An electric heater and thermostat were set inside the apparatus.

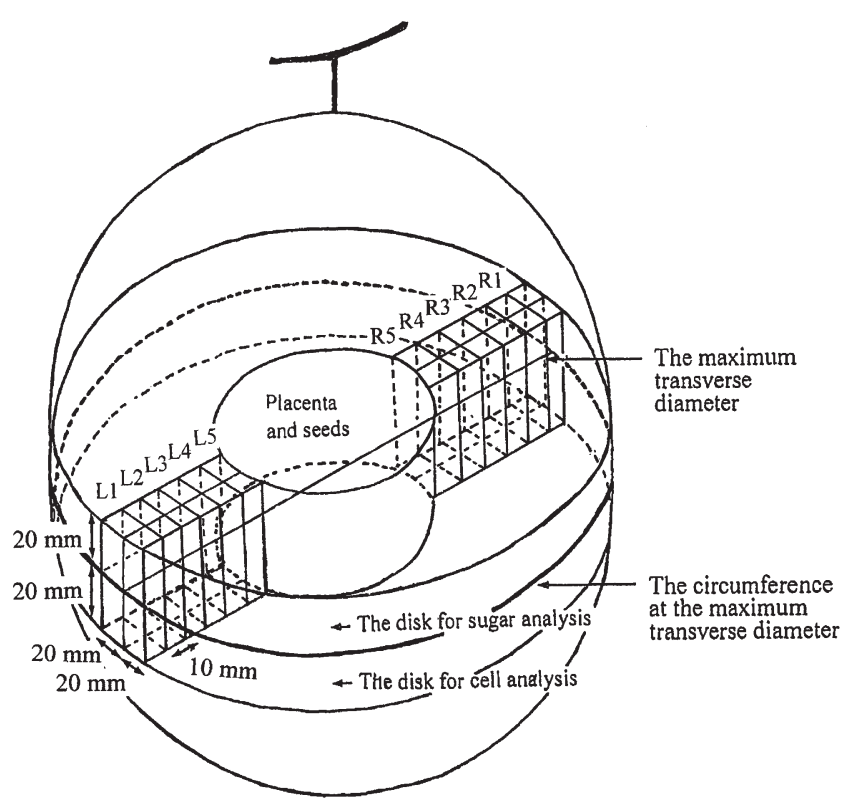

Fig. 2. A schematic of sampling each melon fruit for analysis. Segments taken for cell morphology, enzyme and sugar analyses. An illustration of the collection of rectangular sections for cell size, enzyme and sugar analysis in melon fruit. This is an example for a fruit $50 \mathrm{~d}$ after anthesis.

each block was examined under a microscope. As shown in Figure 3, the maximum dimension of individual cells on the longest horizontal diameter of the segments was measured.

Preparations for biochemical analyses. Segments L3 and R3 from the peduncle-side cross-section were used for enzyme analysis (one each) and for sugar analysis (one each) (Fig. 2).

Fresh melon tissue was ground in a chilled mortar using a 1:3 tissue:buffer ratio with 3-morpholinopropanesulfonic acid (Mops)- $\mathrm{NaOH}$ (50 mм, pH 7.5), 5 mм $\mathrm{MgCl}_{2}, 1$ mм Na 2 EDTA, $2.5 \mathrm{~mm}$ dithiothreitol, and $0.05 \%(\mathrm{v} / \mathrm{v})$ polyoxyethylene$p$-isooctylphenol (Triton X-100; Nacalai Tesque, Kyoto, Japan).
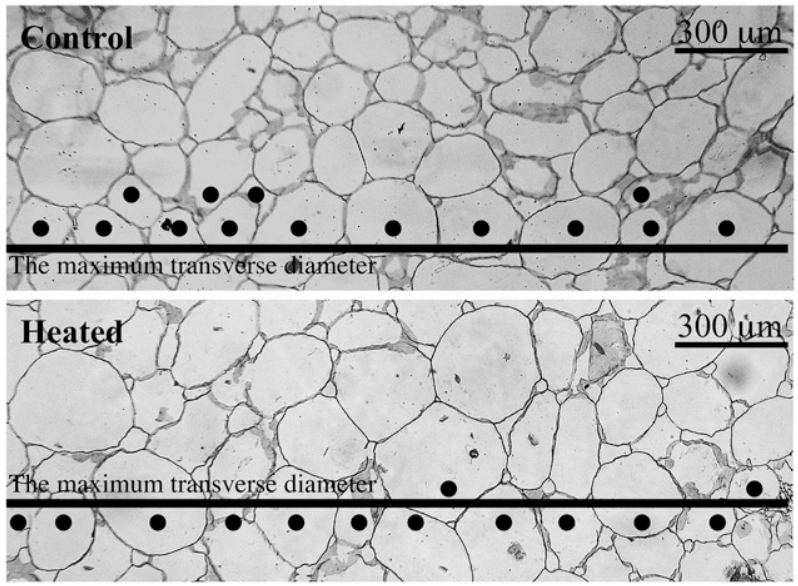

Fig. 3. An illustration of the measurement of cell size of melon fruit $16 \mathrm{~d}$ after anthesis. Black dots indicate the actual cells measured.

Homogenates were centrifuged at $11,000 \mathrm{~g}_{\mathrm{n}}$ for $15 \mathrm{~min}$ at $4{ }^{\circ} \mathrm{C}$ and the supernatants were removed and stored at $-33{ }^{\circ} \mathrm{C}$ until analysis. All chemicals were purchased from Nacalai Tesque unless otherwise indicated.

ACID Invertase ASSAY. AI activity was determined in $100-\mu \mathrm{L}$ reaction mixtures containing $20 \mu \mathrm{L}$ supernatant, $50 \mathrm{~mm}$ citratephosphate ( $\mathrm{pH} 4.8$ ), and $66 \mathrm{~mm}$ sucrose. Mixtures were incubated at $35^{\circ} \mathrm{C}$ for $30 \mathrm{~min}$. A $10-\mu \mathrm{L}$ aliquot of the reaction was ended by adding $1.5 \mu \mathrm{L}$ of Glucose $\mathrm{C} 2$ (Wako Pure Chemical Industries, Osaka, Japan), and the amount of glucose produced was measured by the Mutarotase-GOD method (Miwa et al., 1972).

Sucrose Phosphate synthase assay. Two hundred microliters of supernatant was dialyzed twice for 30 min against 200 $\mathrm{mL}$ of $10 \mathrm{~mm}$ Mops-NaOH by oscillatory microdialysis system (Cosmo Bio, Tokyo, Japan) and diluted 1:8 in deionized water. SPS activity was determined in $100-\mu \mathrm{L}$ reaction mixtures containing $40 \mu \mathrm{L}$ diluted dialyzed extract, $50 \mathrm{~mm}$ Mops- $\mathrm{NaOH}$ ( $\mathrm{pH} 7.5$ ), $5 \mathrm{~mm} \mathrm{MgCl}_{2}, 12 \mathrm{~mm}$ D-fructose-6-phosphate disodium salt (fructose 6-P), $12 \mathrm{mmm}$ D-glucose-6-phophate dipotassium salt hydrate (glucose 6-P), and $12 \mathrm{~mm}$ uridine-5' -diphosphoglucose disodium salt. Mixtures were incubated at $35^{\circ} \mathrm{C}$ for $30 \mathrm{~min}$. The reaction was ended after $12 \mathrm{~min}$ with the addition of $200 \mu \mathrm{L}$ of $30 \%(\mathrm{w} / \mathrm{v}) \mathrm{KOH}$. After cooling, $1.8 \mathrm{~mL}$ of $0.14 \%(\mathrm{w} / \mathrm{v})$ anthrone in $13.8 \mathrm{M} \mathrm{H}_{2} \mathrm{SO}_{4}$ was added and the solutions were incubated in a $40{ }^{\circ} \mathrm{C}$ water bath for $20 \mathrm{~min}$. Once cooled, color development in the solutions was measured at $620 \mathrm{~nm}$.

Protein Content assay. Protein content in each extract was determined by the Bradford protein assay (Bradford, 1976) with bovine serum albumin as the standard. Briefly, a 50- $\mu \mathrm{L}$ aliquot of each extract was assayed with this added to $2.5 \mathrm{~mL}$ of Coomassie protein assay kit (available on the web page), and after that, the absorbance at $595 \mathrm{~nm}$ was measured.

SuCROSE, GLUCOSE, AND FRUCTOSE ANALYSES. For sugar analyses, segments from the peduncle-side cross-section were wrapped in cheesecloth and squeezed using pincers to collect juice into a beaker. All procedures in this section, except boiling to inactivate enzymes, were done at less than $4{ }^{\circ} \mathrm{C}$. The juice was heated in boiling water for $20 \mathrm{~min}$ to inactivate enzymes, diluted 1:10 in distilled water, and centrifuged at $8000 \mathrm{~g}_{\mathrm{n}}$ for $15 \mathrm{~min}$. The supernatant was filtered through a $0.45-\mu \mathrm{m}$ filter, and $10 \mu \mathrm{L}$ of the filtrate was applied to a high-performance liquid chromatograph (LC-10ADvp; Shimadzu, Kyoto, Japan) equipped with an 
analytical column (Shim-pack SCR-101C; Shimadzu) heated to $80{ }^{\circ} \mathrm{C}$ by a column oven (CTO-10Avp; Shimadzu) and a refractive index detector (RID-10A; Shimadzu). Sampling was carried out at $0.8 \mathrm{~mL} \cdot \mathrm{min}^{-1}$ by an autosampler (SIL20AC; Shimadzu).

\section{Results}

Fruit Growth. The minimum temperature in the heating boxes was $\approx 20{ }^{\circ} \mathrm{C}$, which was almost $10{ }^{\circ} \mathrm{C}$ higher than that in the control greenhouse (Fig. 4). Fruit length, diameter, and weight did not differ significantly between heated and control fruit at any DAA (Fig. 5).

Cell size. Cell size of heated fruit at 16 DAA was significantly larger $(P<0.05)$ than that of control fruit, but cell size of heated fruit at 50 DAA was significantly smaller than that of control fruit (Fig. 6). Cell size at 26 DAA did not differ between treatments. Cell growth over the 10 -d periods from 16 to $26 \mathrm{DAA}$ and from 26 and $50 \mathrm{DAA}$ were 2.3 and $1.7 \mu \mathrm{m} \cdot \mathrm{d}^{-1}$, respectively, for the heated fruit and 6.3 and $4.1 \mu \mathrm{m} \cdot \mathrm{d}^{-1}$, respectively, for control fruit.

ENZYME ACTIVITY. AI activity decreased with fruit development in both treatments (Fig. 7). There was no significant difference in AI activity between treatments at any DAA resulting from high variance in the values (Fig. 7). SPS activity of heated fruit at 16 and 26 DAA was significantly higher than in control

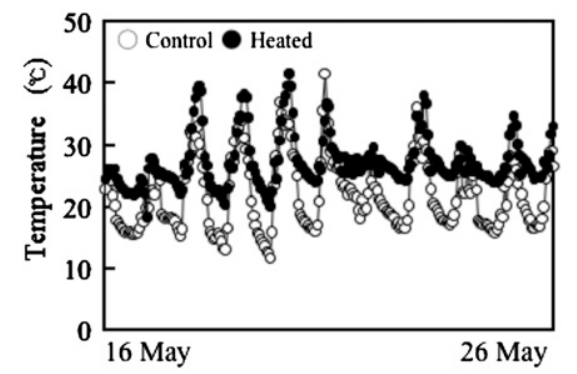

Fig. 4. Ambient temperature in the plastic film greenhouse and in the heating box recorded every hour during the nighttime heating treatment period.

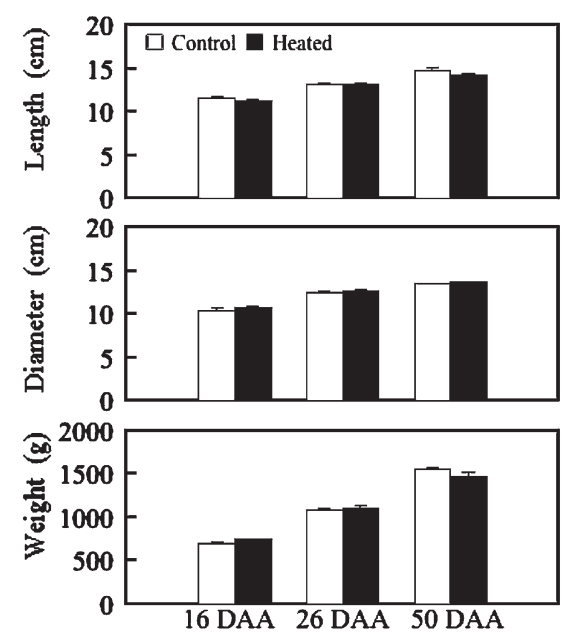

Fig. 5. Effect of nighttime heating of fruit on the growth of melon fruit. Fruit were heated during the night for $10 \mathrm{~d}$ from 6 to $16 \mathrm{~d}$ after anthesis (DAA) and collected at 16,26 , and 50 DAA. Vertical bars are $\mathrm{SE}(\mathrm{n}=5)$. fruit (Fig. 8). SPS activity in both treatments at 50 DAA was less than $7 \mu \mathrm{mol} \cdot \mathrm{min}^{-1} \cdot \mathrm{mg}^{-1}$ protein.

Sugar Content. Sucrose was not detected in either treatment at 16 or 26 DAA (Fig. 9). Mean glucose $\left(6.4 \mathrm{~g} \cdot \mathrm{L}^{-1}\right)$ and

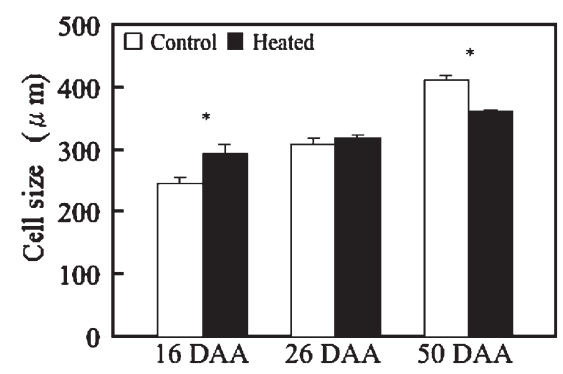

Fig. 6. Effect of nighttime heating of fruit on cell size in central portions of melon fruit. Fruit were heated for $10 \mathrm{~d}$ from 6 to $16 \mathrm{~d}$ after anthesis (DAA) and collected at 16,26, and 50 DAA. *Significantly different at $P<0.05$ by $t$ test. Vertical bars are SE $(n=5)$.

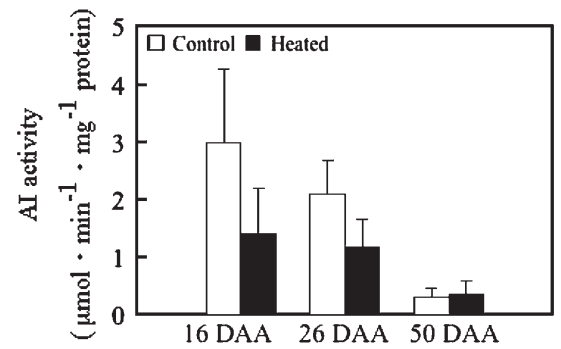

Fig. 7. Effect of nighttime heating of fruit on acid invertase (AI) activity of melon fruit. Fruit were heated for $10 \mathrm{~d}$ from 6 to $16 \mathrm{~d}$ after anthesis (DAA) and collected at 16,26 , and 50 DAA. Vertical bars are SE $(n=5)$.

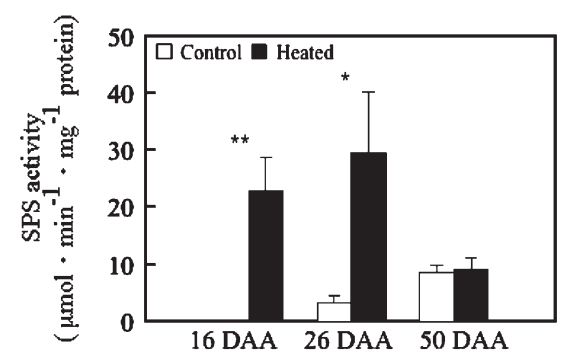

Fig. 8. Effect of nighttime heating of fruit on sucrose phosphate synthase (SPS) activity of melon fruit. Fruit were heated for $10 \mathrm{~d}$ from 6 to $16 \mathrm{~d}$ after anthesis (DAA) and collected at 16,26, and 50 DAA. *, ** Significantly different at $P<$ 0.05 and 0.01 by $t$ test. Vertical bars are SE $(\mathrm{n}=5)$.

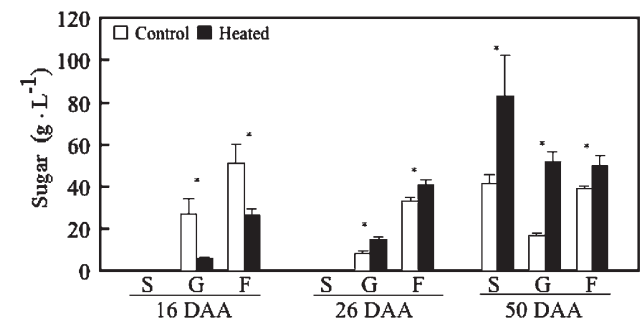

Fig. 9. Effect of nighttime heating of fruit on sugar content of melon fruit [sucrose (S), glucose $(\mathrm{G})$, fructose $(\mathrm{F})]$. Fruit were heated for $10 \mathrm{~d}$ from 6 to $16 \mathrm{~d}$ after anthesis (DAA) and collected at 16,26, and 50 DAA. *Significantly different at $P<0.05$ by $t$ test. Vertical bars are SE $(\mathrm{n}=5)$. 
fructose $\left(26.9 \mathrm{~g} \cdot \mathrm{L}^{-1}\right)$ content of juice from heated fruit at 16 DAA was $24 \%$ and $53 \%$ of that of control fruit, respectively, but glucose $\left(15.0 \mathrm{~g} \cdot \mathrm{L}^{-1}\right)$ and fructose $\left(41.0 \mathrm{~g} \cdot \mathrm{L}^{-1}\right)$ content of juice from heated fruit at 26 DAA was greater than that of control fruit (8.5 and $34.5 \mathrm{~g} \cdot \mathrm{L}^{-1}$, respectively). Sucrose, glucose, and fructose content at 50 DAA of juice from heated fruit was 2.0, 3.0, and 1.3 times higher, respectively, than those in control fruit (Fig. 9).

\section{Discussion}

Nighttime heating of fruit during early stages of fruit growth accelerated the growth of melon (Kano, 2006; Kano and Fukuoka, 2006) and watermelon fruit (Kano et al., 2008). However, the results shown in Figure 5 suggest that this accelerated growth did not occur in the present experiment.

In the present study, at 16 DAA, cells of fruit heated early in their development were larger than those of control fruit. Nighttime heating of fruit in early stages of fruit development has been shown to accelerate cell enlargement in melon (Kano, 2006) and watermelon fruit (Kano et al., 2008). Moreover, cell enlargement was greater in melon fruit of plants grown at higher temperatures compared with that of plants grown at lower temperatures (Kano and Fukuoka, 2006). Taken together, these results suggest that nighttime heating of melon fruit in early stages of development accelerates cell expansion, but cells of heated fruit in the present study were smaller than those of control fruit at the later stage of development (50 DAA). Cells of melon fruit heated early in development enlarged little during the later period of development, resulting in fruit that were the same size as control fruit (Kano, 2006). Cells of grape berries (Vitis vinifera L.) grown at higher temperatures during early development were smaller at the later stages of development than those grown at lower temperatures (Yukinaga, 1964). In the present study, cell growth rate of heated fruit was lower than that of control fruit at each stage of development. These results suggest that the growth of cells subjected to high temperatures early in fruit development is suppressed during later stages of development. Therefore, fruit heated during early stages of development mature earlier and grow little during later stages of development, but cells at the later development stage still support increased sucrose content.

SPS activity was higher in heated fruit than in control fruit at 16 and 26 DAA. In heated fruit compared with control fruit, hexose content at 16 DAA was lower, and hexose content at 26 DAA and sucrose and hexose content at 50 DAA were higher. Increases in the proportion of sucrose in melon fruit (Gao et al., 1999; Hubbard et al., 1989; Hubbard and Pharr, 1990; Lingle and Dunlap, 1987; McCollum et al., 1988; Pharr and Hubbard, 1994) and butter squash (Cucurbita maxima D.) at maturation (Irving et al., 1997) were associated with a decline in AI activity and an increase in SPS activity. SPS activity is important for determining the soluble sugar content of fruit of many species (Hubbard et al., 1991). These reports show that fruit maturation is accompanied by an increase in SPS activity, resulting in an increase in fruit sucrose content. Increased sucrose content of melon (Kano, 2006) and watermelon fruit (Kano et al., 2008) by nighttime heating early in development and high sucrose content in netted melon fruit grown at higher nighttime temperature (Kano and Fukuoka, 2006; Suzuki and Masuda, 1961; Suzuki et al., 1986, 1993) are considered to be results of higher temperature accelerating fruit development. Therefore, it is reason- able to consider that higher nighttime temperature can induce an increase in SPS activity and an increase in sucrose content in heated fruit because the rate at which cells mature is accelerated. Because nighttime heating may induce earlier cell maturity, despite lower SPS activity at 50 DAA, sucrose content was higher in heated fruit at 50 DAA (Fig. 9). Lower hexose content in heated fruit at 16 DAA can be attributed to the use of hexose for cell growth and maturation during the night at higher temperatures. Hexose seems to be actively accumulated actively in heated fruit at 26 DAA because cells are nearly mature, which may explain why sucrose content is high in heated fruit.

Therefore, the following conclusions can be made regarding the relationship among cell size, SPS activity, and sucrose accumulation in melon fruit. Cells of untreated fruit mature later and they only have a short duration of active sucrose accumulation. Cells of melon fruit grown with nighttime heating during early stages of fruit development grow larger and mature early, which induces an earlier increase in SPS activity, which in turn increases the duration of sucrose accumulation, leading to high soluble sugar content in the fruit.

\section{Literature Cited}

Bradford, M.M. 1976. A rapid and sensitive method for the quantitation of microgram quantities of protein utilizing the principle of protein-dye binding. Anal. Biochem. 72:248-254.

Chrost, B. and K. Schmitz. 1997. Changes in soluble sugar and activity of $\alpha$-galactosidases and acid invertase during muskmelon (Cucumis melo L.) fruit development. J. Plant Physiol. 151:41-50.

Gao, Z., M. Petreikov, E. Zamski, and A.A. Schaffer. 1999. Carbohydrate metabolism during early fruit development of sweet melon (Cucumis melo). Physiol. Plant. 16:1-8.

Hubbard, N.L., S.C. Huber, and D.M. Pharr. 1989. Sucrose phosphate synthase and acid invertase as determinants of sucrose concentration in developing muskmelon (Cucumis melo L.) fruits. Plant Physiol. 91:1527-1534.

Hubbard, N.L. and D.M. Pharr. 1990. Sucrose metabolism in ripening muskmelon fruit as affected by leaf area. J. Amer. Soc. Hort. Sci. 115: 798-802.

Hubbard, N.L., D.M. Pharr, and S.C. Huber. 1991. Sucrose phosphate synthase and other metabolizing enzymes in fruits of various species. Physiol. Plant. 82:191-196.

Irving, D.E., P.L. Hurst, and J.S. Ragg. 1997. Changes in carbohydrates and carbohydrate metabolizing enzymes during the development, maturation, and ripening of buttercup squash (Cucurbita maxima D. 'Delica'). J. Amer. Soc. Hort. Sci. 122:310-314.

Kano, Y. 2003. Effect of GA and CPPU treatments on cell size and type of sugars accumulated in japanese pear fruit. J. Hort. Sci. Biotechnol. 78:331-334.

Kano, Y. 2004. Effect of SADH treatment on cell size and kind of sugars accumulated in melon fruits. J. Hort. Sci. Biotechnol. 79:1417.

Kano, Y. 2006. Effect of heating fruit on cell size and sugar accumulation in melon fruit (Cucumis melo L.). HortScience 41:14311434.

Kano, Y. 2009. Effects of mechanically restricting melon (Cucumis melo L.) fruit growth on cell size and sugar accumulation. Environ. Control Biol. 47:1-12.

Kano, Y. and N. Fukuoka. 2006. Comparison of cell size and sugar accumulation in melons (Cucumis melo L.) grown early or late in summer. Environ. Control Biol. 44:93-102.

Kano, Y., Y. Ikeshita, Y. Kanamori, and N. Fukuoka. 2008. Effects of night-heating of fruit on cell size and sucrose accumulation in the outer portion of watermelon (Citrullus lanatus Matsum. et Nakai). HortScience 43:792-794. 
Lingle, S.E. and J.R. Dunlap. 1987. Sucrose metabolism in netted muskmelon fruit during development. Plant Physiol. 84:386-389.

McCollum, T.G., D.J. Huber, and D.J. Cantliffe. 1988. Soluble sugar accumulation and activity of related enzymes during muskmelon fruit development. J. Amer. Soc. Hort. Sci. 113:399-403.

Miwa, I., J. Okuda, K. Maeda, and G. Okuda. 1972. Mutarotase effect on colorimetric determination of blood glucose with $\beta$-D-glucose oxidase. Clin. Chim. Acta 37:538-540.

Pharr, D.M. and N.L. Hubbard. 1994. Melons: Biochemical and physiological control of sugar accumulation, p. 25-37. In: C.J. Amtzen and E.M. Ritter (eds.). Encyclopedia of agricultural science. Vol. 3. Academic Press, San Diego, CA.
Suzuki, E. and S. Masuda. 1961. Studies on fruit development of muskmelons. 5. Sugar content in the fruit of Earl's Favorite. Bul. Fac. Educ., Shizuoka Univ. Natural Sci. Ser. 12:205-213.

Suzuki, M., M. Nakahara, and N. Asano. 1993. Relationship of seeding time, especially cumulative temperature, and vegetative growth of netted melon (Cucumis melo L. var. reticulatus) cultivars in retarded cultivation. Bul. Hort. Inst. Ibaraki Agr. Ctr. 1:57-64.

Suzuki, T., S. Nakamura, M. Toda, and A. Ozawa. 1986. Temperature and humidity control in growing of greenhouse muskmelon. Bul. Shizuoka Agr. Expt. Sta. 31:47-54.

Yukinaga, H. 1964. Studies on the thermal conditions of grapes. PhD thesis, Kyoto Univ., Kyoto, Japan. 